\title{
Nitrimidazine in the treatment of trichomoniasis
}

\author{
M. MOFFETT, M. I. MCGILL, C. B. S. SCHOFIELD, AND G. MASTERTON \\ Department of Venereology, 67 Black Street, Glasgow C4
}

In the Glasgow area, Trichomonas vaginalis continues to be the principal cause of nongonococcal inflammatory conditions of the female genital tract. The original systemic trichomonicidal drug, metronidazole, represented a great therapeutic advance and continues to give good results a decade after its introduction. However, it is not invariably successful, as was noted in the early days by various authors (Rodin, King, Nicol, and Barrow, 1960; Willcox, 1960; Watt and Jennison, 1962). The failure rate was then around 10 per cent. but in this area at least it is now 15 per cent. despite varying the dosage and the length of the course of treatment.

Although this is clinically acceptable there is now a need for an alternative systemic treatment.

Nitrimidazine, an imidazole derivative, has recently been made available, and an assessment of its efficacy forms the subject of the present communication.

Received for publication October 12, 1970

\section{Material and methods}

92 female patients (Table I) suffering from trichomoniasis were given $250 \mathrm{mg}$. nitrimidazine twice daily for 6 days. Patients in transit, previous defaulters, and pregnant women were excluded from the trial. We also planned to treat as many male consorts as possible with the same course of nitrimidazine regardless of whether they had trichomoniasis or not.

The women were re-examined as soon as possible after their initial treatment and again after the first and second menstrual periods following therapy.

Clinical impressions were ignored and the initiag diagnosis and specific proof of cure were based solely on the bacteriological findings.

Other venereal diseases were diagnosed in 79 cases (Table II).

\section{Investigations}

Three methods were used to confirm the diagnosis of trichomoniasis.

(1) CULTURE

Urethral and cervical or vaginal specimens were taken in

TAB LE I Age and marital status of 92 patients

\begin{tabular}{|c|c|c|c|c|c|c|c|}
\hline \multirow{2}{*}{ Marital status } & \multicolumn{7}{|c|}{ Age (yrs) } \\
\hline & $14-19$ & $20-24$ & $25-29$ & $30-34$ & $35-39$ & $40-44$ & Total \\
\hline Single & 30 & 12 & 5 & 2 & 1 & - & 50 \\
\hline Married & 3 & 14 & 16 & 5 & 3 & 1 & 42 \\
\hline Total & 33 & 26 & 21 & 7 & 4 & 1 & 92 \\
\hline
\end{tabular}

T A B LE I I Patients suffering from other venereal diseases, by age group

\begin{tabular}{|c|c|c|c|c|c|c|c|}
\hline \multirow{2}{*}{ Diagnosis } & \multicolumn{7}{|c|}{ Age group (yrs) } \\
\hline & $14-19$ & $20-24$ & $25-29$ & $30-34$ & $35-39$ & $40-44$ & Total \\
\hline Recent or concurrent gonorrhoea & 19 & 13 & 14 & 3 & 2 & 1 & 52 \\
\hline Vaginal candidosis & 4 & 4 & 3 & - & 2 & 1 & 14 \\
\hline Previous trichomoniasis & 2 & 4 & 4 & - & 3 & - & 13 \\
\hline
\end{tabular}


Stuart's transport medium and later grown in the Laboratory in Feinberg-Whittington media.

\section{(2) PHASE CONTRAST MICROSCOPY}

Specimens suspended in isotonic saline were examined by phase contrast microscopy to demonstrate the living trichomonad. (We used the Wild universal phase condenser, annular diaphragm 50/100 with phase objective 100 H.I.)

\section{(3) CERVICAL EXFOLIATIVE CYTOLOGY}

Material obtained from the cervical scrape was stained (Papanicolaou) to demonstrate the trichomonad.

Culture was carried out on urethral and cervical (or vaginal) secretions in the case of every patient at the time of the initial examination and at the follow-up examinations. In addition, phase contrast microscopy was carried out in 65 per cent. and cervical cytology in 75 per cent. of the patients.

Invariably, the test of cure in these follow-up examinations was the failure to demonstrate the protozoon by the same procedure as had given the initial diagnosis.

\section{Results}

Of the 92 patients originally treated, sixteen ( 17 per cent.) did not return for further examination, and nothing is known of their response to treatment. Accordingly, 76 patients were followed up; seventeen of these defaulted during surveillance but they were known to have been bacteriologically clear at the time of their last follow-up examination. 47 patients (51 per cent.) completed the 2-month surveillance period satisfactorily and were cured (Table III). Finally, there were twelve cases in which Trichomonas vaginalis was demonstrated at some stage in the follow-up examinations (Table IV).
Five of these twelve cases were regarded as primary failures and seven as secondary failures. Primary failure was defined as the persistence of the trichomonad at the first examination immediately after therapy. In secondary failure, the trichomonad reappeared after the patient had been shown to be bacteriologically clear at an earlier examination.

Concomitant prophylactic treatment (with $250 \mathrm{mg}$. nitrimidazine twice daily for 6 days) was given to 28 (31 per cent.) of the male consorts whose sexual partners all responded to treatment. All our treatment failures occurred in women whose consorts remained untreated.

\section{Discussion}

The interpretation of our clinical results is not simplified by the behaviour pattern of some of the women included in this clinical trial. Our difficulties mainly arose from the erratic attendance of unreliable promiscuous patients. Since this lack of discipline may have influenced the results, it would seem appropriate to consider the possible effects.

\section{(1) ERRATIC ATTENDANCE}

Our patients were quite unreliable and unpredictable in their out-patient attendance. Fourteen patients (15 per cent.) missed their booked appointments but reappeared for no apparent reason at a later date. One-fifth attended once, received their treatment, and failed to return for any follow-up examination. Eventually one-third of those treated defaulted without completing their period of surveillance. Their non-appearance may have been due to a belief that they were already cured, because nitrimidazine brings about very rapid local symptomatic relief. But with-

TABLE I I Results of treatment

\begin{tabular}{|c|c|c|c|c|c|c|c|c|c|c|c|c|c|c|}
\hline \multirow[t]{2}{*}{ Time of testing } & \multirow{2}{*}{$\begin{array}{l}\text { Patients } \\
\text { under } \\
\text { surveillance }\end{array}$} & \multirow{2}{*}{$\begin{array}{l}\text { Patients } \\
\text { defaulting }\end{array}$} & \multirow{2}{*}{$\begin{array}{l}\text { Patients } \\
\text { missing } \\
\text { appointment }\end{array}$} & \multirow{2}{*}{$\begin{array}{l}\text { Patients } \\
\text { actually } \\
\text { examined }\end{array}$} & \multirow{2}{*}{$\begin{array}{l}\text { Trichomonas } \\
\text { vaginalis } \\
\text { not found }\end{array}$} & \multicolumn{7}{|c|}{ Trichomonas vaginalis present } & \multirow[t]{2}{*}{ Total } & \multirow{2}{*}{$\begin{array}{l}\text { Percentage } \\
\text { known } \\
\text { failure rate }\end{array}$} \\
\hline & & & & & & 1 & 2 & 3 & 4 & 5 & 6 & $7 \star$ & & \\
\hline $\begin{array}{l}\text { Initial } \\
\text { attendance }\end{array}$ & 92 & 一 & - & 一 & - & 39 & 15 & 11 & 6 & 5 & 1 & 15 & 92 & 一 \\
\hline $\begin{array}{l}\text { After } \\
\text { completion } \\
\text { of treatment }\end{array}$ & 92 & 16 & 10 & 66 & 61 & & 2 & & & 2 & & 1 & $5^{A}$ & $\underset{6 \cdot 6 \mathrm{C}}{\text { Minimal }}$ \\
\hline $\begin{array}{l}\text { After first } \\
\text { menstrual } \\
\text { period }\end{array}$ & 71 & 9 & 4 & 58 & 53 & & 1 & & & 2 & 1 & 1 & $5^{\mathrm{B}}$ & - \\
\hline $\begin{array}{l}\text { After second } \\
\text { menstrual } \\
\text { period }\end{array}$ & 57 & 8 & - & 49 & 47 & & & & & & 1 & 1 & $2^{B}$ & - \\
\hline $\begin{array}{l}\text { A Primary failu } \\
\text { B Secondary fai } \\
\text { C See discussio }\end{array}$ & & $\begin{array}{l}\star B a c \\
\text { 1. } \mathrm{W} \\
\text { 2. } \mathrm{Ph} \\
\text { 3. } \mathrm{Ph}\end{array}$ & $\begin{array}{l}\text { iology code } \\
\text { film (phase mi } \\
\text { e microscopy } \\
\text { e microscopy }\end{array}$ & $\begin{array}{l}\text { oscopy) }+ \\
\text { culture } \\
\text { cervical sm }\end{array}$ & $\begin{array}{l}\text { culture }+ \text { cervic } \\
\text { ear }\end{array}$ & al sr & & & & & ase & $\begin{array}{l}\text { e }+c \\
\text { micro } \\
\text { e only } \\
\text { al sme }\end{array}$ & $\begin{array}{l}\text { cervical } \\
\text { oscopy o } \\
\text { y } \\
\text { ear only }\end{array}$ & $\begin{array}{l}\text { smear } \\
\text { nly }\end{array}$ \\
\hline
\end{tabular}


TABLE IV Treatment failures

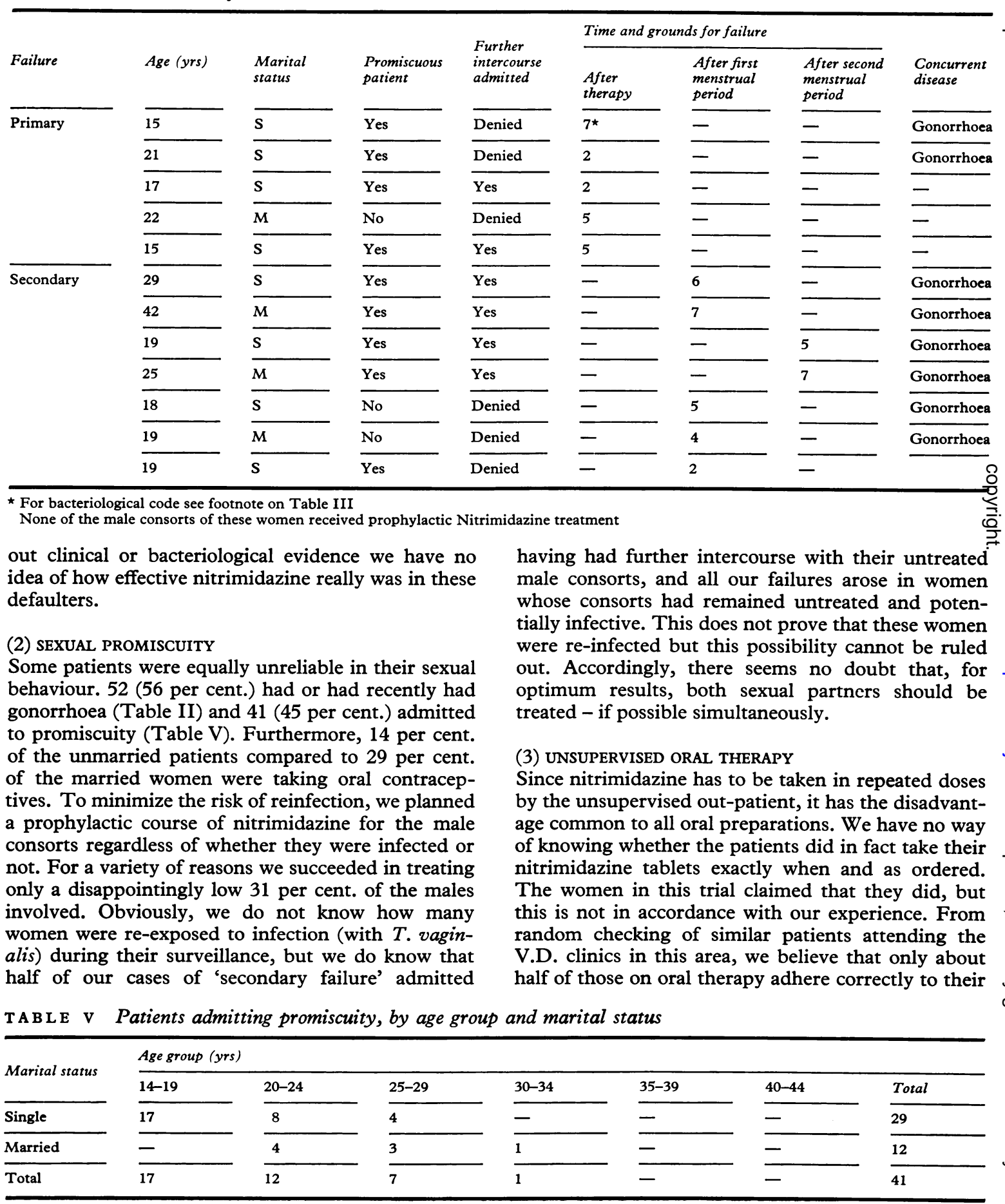


treatment schedule. Hence clinical results - and this trial is no exception - depend upon the amount of drug the patient decides to take rather than upon that prescribed.

In view of these difficulties and in particular of the enigma of the defaulting patient, any attempt at statistical analysis would be unrealistic.

Because of the defaulters and the impulsive attenders' we cannot give an accurate per cent. rate, but we can still draw valid conclusions from our observations:

(A) Nitrimidazine did not appear to cause any sideeffects in any of the patients.

(B) It obviously gave very rapid local symptomatic relief.

(C) Our overall known minimum failure rate was 16 per cent. of those followed up. On further analysis we had:

(a) A known minimal primary failure rate of 6.6 per cent. of those followed-up.

(b) A known minimal secondary failure rate of $\mathbf{9 . 4}$ per cent. of those followed-up.

The secondary failure rate is difficult to interpret since we can never be sure whether the failure is due to relapse or to re-infestation after further exposure to risk.

Thus we regard the primary known failure rate as the most significant. Using this as a yardstick, we found little to choose between nitrimidazine and metronidazole. Nitrimidazine has to be taken less frequently by the patient, which might be considered an advantage.

\section{(4) RESPONSE TO RE-TREATMENT}

With one exception, all our original cases of treatment failure responded to further antitrichomonal therapy. This took the form either of a prolonged course of nitrimidazine totalling $250 \mathrm{mg}$. twice daily for 12 days or of a course of metronidazole $200 \mathrm{mg}$. thrice daily for 14 days.

This latter observation is interesting since we had earlier found that nitrimidazine was successful in those women who had failed to respond to metronidazole. Obviously the reverse is also true and perhaps there is an explanation other than a pharmacological one. Was the belated success simply due to the patient's carrying out the treatment correctly at the second attempt?

\section{Summary}

92 female patients suffering from trichomoniasis were treated with nitrimidazine, one tablet $250 \mathrm{mg}$. twice daily for 6 days, and 76 were followed-up. The drug produced a very rapid alleviation of local symptoms and no side-effects were noted. Treatment was successful in all women whose consorts had been given a prophylactic course of nitrimidazine; in all our treatment failures, the male partner had not received antitrichomonal treatment. The overall 'possible' failure rate was 16 per cent., but the known failure rate was 6.6 per cent. of those patients who were followed-up.

On this basis, we could find no significant difference between the therapeutic effects of nitrimidazine and metronidazole. Re-treatment with nitrimidazine was often effective in cases in which metronidazole had failed - and the reverse was also true.

Nitrimidazine can be given in a shorter more simplified course, and we believe that it offers a valuable means of systemic treatment for trichomoniasis.

We wish to thank Messrs. Carlo Erba who provided the nitrimidazine used in this trial.

\section{References}

Rodin, P., King, A. J., Nicol, C. S., and Barrow, J. (1960) Brit. F. vener. Dis., 36, 147

WATT, L., and JENNISON, R. F. (1962) Brit. med. F., 1, 276

Willcox, R. R. (1960) Brit. F. vener. Dis., 36, 175

\section{Le Nitrimidazine dans le traitement de la trichomonase}

\section{SOMMAIRE}

92 femmes atteintes de trichomonase furent traitées avec le Nitrimidazine, un comprimé à $250 \mathrm{mg}$. deux fois par jour pendant 6 jours, et 76 furent suivies. Le médicament amena une rapide amélioration des symptômes locaux et aucun effet secondaire ne fut noté. Le traitement a réussi chez toutes les femmes dont les partenaires avaient reçu une série prophylactique de Nitrimidazine; dans tous les échecs thérapeutiques, les partenaires n'avaient pas reçu de traitement trichomonicide. Le total du pourcentage 'possible' des échecs fut de 16 pour cent, mais le taux des échecs connus chez les malades suivies fut de 6,6 pour cent.

Sur ces constatations, nous ne trouvons pas de différence entre l'effet thérapeutique du Nitrimidazine et celui du Metronidazole. Un deuxième traitement avec le Nitrimidazine réussit souvent lorsque le Metronidazole avait échoué mais l'inverse fut également observé.

Le Nitrimidazine peut être donné en une série plus courte et plus simplifiée. Nous pensons qu'il représente un moyen valable de traitement de la trichomonase par voie générale. 